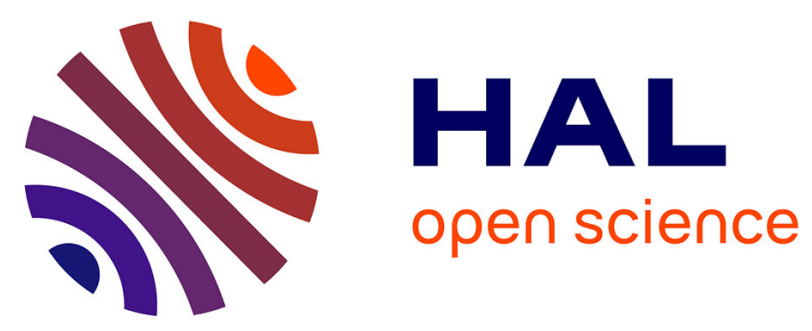

\title{
High prevalence of Mycoplasma genitalium infection and macrolide resistance in patients enrolled in HIV pre-exposure prophylaxis program
}

\author{
M. Deborde, Sabine Pereyre, M. Puges, Cécile Bebear, A. Desclaux, Mojgan \\ Hessamfar, C. Le Roy, Fabien Le Marec, François Dabis, C Cazanave
}

\section{To cite this version:}

M. Deborde, Sabine Pereyre, M. Puges, Cécile Bebear, A. Desclaux, et al.. High prevalence of Mycoplasma genitalium infection and macrolide resistance in patients enrolled in HIV preexposure prophylaxis program. Médecine et Maladies Infectieuses, 2019, 49 (5), pp.347-349. 10.1016/j.medmal.2019.03.007 . hal-02628382

\section{HAL Id: hal-02628382 \\ https://hal.inrae.fr/hal-02628382}

Submitted on 25 Oct 2021

HAL is a multi-disciplinary open access archive for the deposit and dissemination of scientific research documents, whether they are published or not. The documents may come from teaching and research institutions in France or abroad, or from public or private research centers.
L'archive ouverte pluridisciplinaire HAL, est destinée au dépôt et à la diffusion de documents scientifiques de niveau recherche, publiés ou non, émanant des établissements d'enseignement et de recherche français ou étrangers, des laboratoires publics ou privés.

\section{(c) (1) $\$$}

Distributed under a Creative Commons Attribution - NonCommerciall 4.0 International 


\title{
Prévalence élevée d'infection à Mycoplasma genitalium et de résistance aux macrolides chez les usagers de la prophylaxie pré-exposition contre l'infection VIH
}

High prevalence of Mycoplasma genitalium infection and macrolide resistance in patients enrolled in HIV pre-exposure prophylaxis program

\author{
M Deborde ${ }^{1}$, S Pereyre ${ }^{2,3,4}$, M Puges ${ }^{1}$, C Bébéar ${ }^{2,3,4}$, A Desclaux ${ }^{1}$, M Hessamfar ${ }^{5,6,7,8}$, C Le \\ Roy $^{2,3}$, F Le Marec ${ }^{5,6}$, F Dabis $^{5,6,7}$, C Cazanave $^{1,2,3}$
}

${ }^{1}$ Bordeaux University Hospital, Infectious and Tropical Diseases Department, Pellegrin Hospital, Bordeaux, France.

2Bordeaux University, USC EA 3671, Mycoplasma and chlamydia human infections, Bordeaux, France.

${ }^{3}$ French National Institute for Agricultural Research, USC EA 3671, Mycoplasma and chlamydia human infections, Bordeaux, France.

${ }^{4}$ Bordeaux University Hospital, Bacteriological Laboratory, Bordeaux, France.

${ }^{5}$ Bordeaux University, Institute for Public Health, Epidemiology, and Development (ISPED), INSERM U1219 - Bordeaux Population Health, Bordeaux, France.

${ }^{6}$ INSERM, Institute for Public Health, Epidemiology, and Development (ISPED), INSERM U1219 - Bordeaux Population Health, Bordeaux, France.

${ }^{7}$ Bordeaux University Hospital, COREVIH Aquitaine, Bordeaux, France.

${ }^{8}$ Bordeaux University Hospital, Infectious Diseases and Internal Medicine Department, SaintAndré Hospital, Bordeaux, France. 
Corresponding author: Charles Cazanave, MD, PhD, Service des Maladies Infectieuses et Tropicales, Hôpital Pellegrin, Place Amélie Raba-Léon, Bordeaux Cedex 33076, France (email: charles.cazanave@chu-bordeaux.fr, fax: +33 5567960 36; tél : + 335567955 36).

Part of the data was presented at the $18^{\text {th }}$ JNI congress, June $21-23,2017$, St-Malo, France.

Mots clés : prophylaxie pré-exposition ; Mycoplasma genitalium ; macrolides

Keywords: pre-exposure prophylaxis; Mycoplasma genitalium; macrolides 


\section{Résumé}

Objectifs. Déterminer la prévalence et la résistance aux macrolides des infections à $M$. genitalium chez les usagers de PrEP.

Patients et méthodes. Recherche systématique et prospective des infections à M. genitalium à la consultation PrEP du CHU de Bordeaux (inclusion entre janvier 2016 et février 2017).

Résultats. Sur 89 personnes, nous rapportons une prévalence des infections à $M$. genitalium de $10 \%$ (majoritairement asymptomatiques), aussi élevée que celle des autres IST classiquement testées, avec un taux élevé (58 \%) de résistance aux macrolides.

Conclusions. Compte tenu du fort taux de résistance aux macrolides, une recherche systématique de la résistance aux macrolides dans les infections à $M$. genitalium peut être recommandée avant d'envisager une antibiothérapie. 


\section{Summary}

Objectives. Limited data on Mycoplasma genitalium infection has been reported among PrEP users. The aim of this study was to estimate the prevalence and macrolide resistance of $M$. genitalium infection among enrollees in a French PrEP program.

Patients and methods. M. genitalium infection screening was systematically and prospectively proposed to patients of the Bordeaux PrEP program (between January 2016 and February 2017). Macrolide resistance was evaluated in M. genitalium-positive patients.

Results. Among 89 clients, M. genitalium infection prevalence was $10 \%$ (mainly asymptomatic) with a high rate of macrolide resistance (58\%).

Conclusions. Because of a high level of macrolide resistance, a systematic search for $M$. genitalium macrolide resistance associated-mutations may be recommended in PrEP users before initiating the antibiotic therapy. 


\section{Introduction}

Mycoplasma genitalium is a recognized and emerging sexually transmitted pathogen [1]. A meta-analysis reported a strong association between $M$. genitalium and HIV infection, especially in African populations [2]. A cohort study reported a positive relation between M. genitalium infection and the risk of HIV-1 acquisition in African women [3]. Moreover, in a British study of 438 men who had sex with men (MSM), M. genitalium infection was significantly associated with HIV positivity (OR $7.6,95 \% \mathrm{Cl} 3.2$ to $18.7, p<0.001$ ), in contrast to other sexually-transmitted infections (STIS) such as Chlamydia trachomatis and Neisseria gonorrhoeae infections [4].

HIV pre-exposure prophylaxis (PrEP) is predominantly proposed to MSM, in whom many STIs are diagnosed $[5,6]$. No reliable data has been reported on $M$. genitalium infection in such populations in France because the screening of this bacterium is usually not routinely performed. Macrolide antibiotics are the first-line treatment for M. genitalium infections. In the Bordeaux University Hospital, southwestern France, before the PrEP introduction, the prevalence of macrolide resistance-associated mutations among $M$. genitalium-positive patients ranged between $8.3 \%$ [7] and 17.2\% [8]. Macrolide resistance rates up to $40 \%$ have been reported in several countries [9].

The aim of this study was to estimate the prevalence of $M$. genitalium infection among enrollees in a PrEP program. Macrolide resistance was evaluated in $M$. genitalium-positive patients.

\section{Material and methods}

The patients of the Bordeaux PrEP program were included between January 2016 and February 2017, with follow-up until June 2017. Detection of M. genitalium was performed 
using the Aptima ${ }^{\circledR}$ M. genitalium assay (Hologic, USA) at program entry, and then every six months. The search for macrolide resistance-associated mutations in the $23 \mathrm{~S}$ rRNA encoding gene was performed using real-time PCR [10]. Urogenital and anal specimens were prospectively collected. The study was performed with oral informed consent in accordance with French ethical guidelines (CNIL agreement \#2043908).

\section{Results}

A total of 88 MSM and one male to female transgender were registered in the PrEP clinic. Their median age was 34.9 years (interquartile range [IQR], 28.1-44.1). The median follow-up was 6.9 months (IQR, 5.3-9.2). Sixty-three out of 87 respondents (72.4\%) reported at least one previous episode of STI. PrEP was prescribed to 77 (86.5\%) of those registered and 69 came back at least once for a follow-up clinic visit. Regarding STI screening, $N$. gonorrhoeae was the most prevalent and incident bacterium (mainly asymptomatic cases) (Table 1). A total of 26 M. genitalium-positive samples were collected from 18 MSM, nine at baseline and nine during follow-up. The anorectum was the most commonly infected site $(15 / 26$, $57.7 \%)$, followed by the urethra $(9 / 26,34.6 \%)$, and the oropharynx $(2 / 26,7.7 \%)$. Prevalence and incidence of $M$. genitalium and other STIs were high (Table 1). M. genitalium prevalence was $10.1 \%(9 / 89)(95 \%$ confidence interval $[\mathrm{Cl}], 4.7-18.3)$ at baseline, and the incidence was 17.4/100 person-years (PY) $(95 \% \mathrm{Cl}, 9.1-33.5)$ (Table 1). M. genitalium prevalence and incidence per anatomical site were $5.6 \%(1.8-12.6)$ and $11 / 100$ PY $(5.0-14.5)$ in anus, $3.4 \%$ (0.7-9.5) and 3.6/100 PY (0.9-14.5) in first-void urine, and $1.1 \%(0.03-6.1)$ and $1.8 / 100$ PY (0.2-12.5) in oropharynx. The $18 \mathrm{M}$. genitalium-infected patients were predominantly asymptomatic with only two patients presenting with a symptomatic but moderate urethral 
discharge. Notably, the 11 patients with at least one anal M. genitalium-positive sample were all asymptomatic.

The samples from nine $M$. genitalium-positive individuals showed resistance to macrolides, two of which were acquired resistance after first-line macrolide treatment (extended azithromycin regimen in both cases). Five patients' samples presented a wild-type phenotype, and samples from the remaining four patients were not amplified by real-time PCR targeting 23 S rRNA because of low $M$. genitalium DNA load. Overall, excluding patients with non-amplified samples $(n=4)$ and patients with acquired resistance during treatment $(n=2)$, macrolide resistance was detected at baseline in $58 \%(7 / 12)$ of patients.

\section{Discussion}

We reported the first results of a study conducted in a urban PrEP clinic of southwestern France. M. genitalium infection was frequent (prevalence of $10.1 \%$ ) among male attendees. This prevalence was higher than that we had reported in 2016 in a more general population attending our university hospital $(3.4 \%, 95 \% \mathrm{Cl} 2.8-4.2)[11]$.

Prevalence of macrolide resistance in this specific population was also higher than expected. We previously collected 369 M. genitalium-positive urogenital specimens in 2013-2014 in the same hospital and the macrolide resistance rate was $17.20 \%(38 / 221 ; 95 \% \mathrm{Cl} 12.79 \%$ $22.72 \%)$, comparable in both years [8]. In 2016, we reported a prevalence of macrolide resistance in male and female clinical samples of $8.3 \%$ (6/72) [7]. However, in an STI clinic in Australia, the frequency of macrolide resistance reached $100 \%$ in M. genitalium-positive rectal specimens from male patients [12].

Azithromycin, especially the single dosage of $1 \mathrm{~g}$, is associated with the development of macrolide resistance in $M$. genitalium, and is likely to increase the circulation of macrolide- 
resistant strains in the population. Consequently, single-dose azithromycin is no longer recommended in Europe as first-line treatment for non-gonococcal urethritis [13]. The recommended treatment for uncomplicated macrolide-resistant $M$. genitalium infection is moxifloxacin $400 \mathrm{mg}$ once daily for 7-10 days [9]. In this context, prevention measures and condom use should be enhanced.

The asymptomatic anorectal M. genitalium infection was the most frequent presentation. We also previously reported a high frequency (71\%) of asymptomatic carriage of $M$. genitalium [11]. Among Australian MSM, rectal infection was more commonly reported than urethral infections: $42 \%$ and $8 \%$, respectively [14]. Two cases of asymptomatic oropharyngeal infection were also reported in the present study, which is not usually reported in the literature.

Because a positive relation between $M$. genitalium infection and the risk of HIV-1 acquisition has been highlighted in previous studies, and because PrEP users may be a possible silent reservoir for $M$. genitalium transmission, a systematic screening for $M$. genitalium including at least one anal sample appears of public health interest in PrEP programs. Furthermore, the high rate of macrolide resistance in this specific population implies a systematic search for macrolide resistance-associated mutations, as per European recommendations [9]. Molecular technologies present the advantage of treatment guidance.

Macrolide resistance in rectal samples from MSM is also of clinical concern with emerging difficult-to-treat cases. Further studies are required to determine the best antibiotic management of M. genitalium infections in PrEP programs.

\section{Acknowledgments}


$M D, M P, A D, M H$, and $C C$ have designed and conducted the study, and have written the article; CLR for biological analysis; SP and CB for biological support and article writing assistance; FLM for statistical analysis; FD for methodology and writing assistance. 


\section{REFERENCES}

1. Cazanave C, Manhart LE, Bébéar C. Mycoplasma genitalium, an emerging sexually transmitted pathogen. Med Mal Infect 2012;42(9):381-92.

2. Napierela Mavedzenge S, Weiss HA. Association of Mycoplasma genitalium and HIV infection: A systematic review and meta-analysis. AIDS 2009;23(5):611-20.

3. Mavedzenge SN, Van Der Pol B, Weiss HA, Kwok C, Mambo F, Chipato T, et al. The association between Mycoplasma genitalium and HIV-1 acquisition in African women. AIDS 2012;26(5):617-24.

4. Soni S, Alexander S, Verlander N, Saunders P, Richardson D, Fisher M, et al. The prevalence of urethral and rectal Mycoplasma genitalium and its associations in men who have sex with men attending a genitourinary medicine clinic. Sex Transm Infect 2010;86(1):21-4.

5. Kojima N, Davey DJ, Klausner JD. Pre-exposure prophylaxis for HIV infection and new sexually transmitted infections among men who have sex with men. AIDS 2016;30(14):2251-2.

6. Molina J-M, Charreau I, Spire B, Cotte L, Chas J, Capitant C, et al. Efficacy, safety, and effect on sexual behaviour of on-demand pre-exposure prophylaxis for HIV in men who have sex with men: an observational cohort study. The Lancet HIV 2017;4(9):e402-10.

7. Le Roy C, Pereyre S, Hénin N, Bébéar C. 2017 French prospective clinical evaluation of the Aptima Mycoplasma genitalium CE-IVD assay and macrolide resistance detection using three distinct assays. J Clin Microbiol 2017;55(11):3194-200.

8. Le Roy C, Hénin N, Pereyre S, Bébéar C. Fluoroquinolone-resistant Mycoplasma genitalium, Southwestern France. Emerg Infect Dis 2016;22(9):1677-9. 
9. Jensen JS, Cusini M, Gomberg M, Moi H. 2016 European guideline on Mycoplasma genitalium infections. J Eur Acad Dermatol Venereol 2016;30(10):1650-6.

10. Touati A, Peuchant O, Jensen JS, Bébéar C, Pereyre S. Direct detection of macrolide resistance in Mycoplasma genitalium isolates from clinical specimens from France by use of real-time PCR and melting curve analysis. J Clin Microbiol 2014;52(5):1549-55.

11. Pereyre S, Laurier-Nadalié C, Bébéar C, for the investigator group. Mycoplasma genitalium and Trichomonas vaginalis in France: a point prevalence in people screened for sexually transmitted diseases. Clin Microbiol Infect 2017;23(2):122.e1122.e7.

12. Tabrizi SN, Su J, Bradshaw CS, Fairley CK, Wlaker S, Tan LT, et al. Prospective evaluation of ResistancePlus MG, a new multiplex quantitative PCR assay for detection of Mycoplasma genitalium and macrolide resistance. J Clin Microbiol 2017;55(6):1915-9.

13. Moi H, Horner PJ. 2016 European guideline on the management of non-gonococcal urethritis published Euro Surveill 2016;21(22).

14. Slifirski JB, Vodstrcil LA, Fairley CK, Ong JJ, Chow EPF, Chen MY, et al. Mycoplasma genitalium infection in adults reporting sexual contact with infected partners, Australia, 2008-2016. Emerg Infect Dis 2017;23(11):1826-33. 
Table 1. Sexually-transmitted infections diagnosed during the regular screening of 89 HIV PrEP users in Bordeaux University Hospital, Southwestern France.

Tableau 1. Infections sexuellement transmissibles diagnostiquées chez 89 personnes suivies dans le programme PrEP du CHU de Bordeaux.

\begin{tabular}{|c|c|c|c|c|}
\hline & $\begin{array}{c}\text { Cases } \\
\text { diagnosed } \\
\text { at } \\
\text { inclusion }\end{array}$ & $\begin{array}{l}\text { Prevalence } \\
\%[95 \% \mathrm{CI}]\end{array}$ & $\begin{array}{c}\text { Cases } \\
\text { diagnosed } \\
\text { during } \\
\text { follow-up }\end{array}$ & $\begin{array}{l}\text { Incidence } \dagger \\
\%[95 \% \mathrm{CI}]\end{array}$ \\
\hline N. gonorrhoeae* & 11 & $12.4[6.3 ; 21.0]$ & 10 & $19.3[10.4 ; 35.9]$ \\
\hline C. trachomatis* & 11 & $12.4[6.3 ; 21.0]$ & 8 & $15.3[7.7 ; 30.7]$ \\
\hline M. genitalium* & 9 & $10.1[4.7 ; 18.3]$ & 9 & $17.4[9.1 ; 33.5]$ \\
\hline Syphilis & 4 & $4.5[1.2 ; 11.1]$ & 2 & $3.6[0.9 ; 14.3]$ \\
\hline Indeterminate urethritis & 0 & 0 & 5 & $9.1[3.8 ; 21.8]$ \\
\hline
\end{tabular}

PrEP: HIV pre-exposure prophylaxis; $95 \%$ CI: 95\% confidence interval.

* Detected in throat, first-void urine, or rectum

$\dagger$ Incidence per 100 person-years 